\title{
Updating Anostraca (Crustacea, Branchiopoda) distribution in Italy
}

\author{
Graziella MURA \\ Dipartimento di Biologia Animale e dell'Uomo, Università “La Sapienza” di Roma, Viale dell'Università 32, I-00185 Roma, Italy \\ e-mail corresponding author: graziella.mura@uniromal.it
}

\begin{abstract}
In this note recent records of some Anostraca species in Italy are presented. These data widen the known distribution in Italy of Branchipus schaefferi Fischer, 1834, Tanymastix stagnalis Linnaeus, 1758, Chirocephalus ruffoi Cottarelli \& Mura, 1984 and Branchinella spinosa Milne-Edwards, 1840, and illustrate the problem of inadequate knowledge of our territory, at least as far as Anostraca (Branchiopoda) are concerned.
\end{abstract}

\section{INTRODUCTION}

Updated information on the presence and distribution of fairy shrimps in Italy (Rebecchi et al. 1990; Cottarelli \& Mura 1995; Cottarelli et al. 1995; Mura et al. 1999) was recently reviewed (Mura 1999) in an article on the status of Italian Anostraca.

From the maps provided in the above paper (see Mura 1999, Figs 1-3), it is apparent that present knowledge of our anostracan fauna is far from being complete, known range of the species generally reflecting specialist distribution and 'migratory activity', rather than that of the animals themselves.

The results of recent field investigations in several areas of the peninsula contributed new data and partly filled the gap existing, for certain regions of north Italy, in particular. Moreover, further find spots were added to the known distribution of Anostraca occurring in Sardinia.

\section{MATERIALS AND METHODS}

Specimens were collected by means of hand nets and plankton nets (150 $\mu \mathrm{m}$ mesh size), preserved in formaldehyde $4 \%$ or ethanol $80 \%$ and stored in the collections of the authors.

Beside the author (GM) the colleagues contributing specimens to this note are listed below: G. Belmonte (GB); N. Bressi (NB); G. Corbatto (GC); S. Dolce (SD); D. Ferreri (DF); Pepe (RP); G. P. Rossetti (GPR); A. Ruggiero (AR); F. Stoch (FS); F. Tinti (FT); I. Zanutto (IZ); P. Zarattini(P.Z.).

\section{LIST OF FIND SPOTS}

Updated distribution of the anostracan species in Italy is illustrated in Figures 1, 2, 3 for Branchipodidae, Chirocephalidae and Thamnocephalidae, respectively.

\section{Peninsular Italy}

1. Surroundings of Forte Olmi, San Floriano (Muggia, Trieste): $198 \mathrm{~m}$ a.s.1., $13^{\circ} 43^{\prime} 56^{\prime \prime} \mathrm{N}, 4^{\circ} 36^{\prime} 18^{\prime \prime} \mathrm{E}$. Small puddle, $(2 \times 1 \mathrm{~m}, 0.1 \mathrm{~m}$ maximum depth $)$ in a field, formed by flooding of vehicles tracks.

2. Nearby Sablici sources, Doberdò del Lago (Gorizia): 9 m a.s.l., $13^{\circ} 34^{\prime} 19^{\prime \prime} N, 45^{\circ} 48^{\prime} 30^{\prime \prime}$. Small temporary pool $(4 \times 2 \mathrm{~m}, 0.4 \mathrm{~m}$ maximum depth), in a field, in the ruts left by vehicles.

3. Military area of Borgo Grotta Gigante (Sgonico, Trieste): $285 \mathrm{~m}$ a.s.1, $13^{\circ} 45^{\prime} 49^{\prime \prime} \mathrm{N}, 45^{\circ} 42^{\prime} 10^{\prime \prime} \mathrm{E}$. Several pools of reduced extension (2-4 m long, $0.4 \mathrm{~m}$ maximum depth), elliptical in shape, formed by flooding of the ruts left by military vehicles.

4. Villaggio del Pescatore quarry, Duino-Aurisina (Trieste): $1 \mathrm{~m}$ a.s.1., $13^{\circ} 35^{\prime} 29^{\prime \prime N}, 45^{\circ} 46^{\prime} 39^{\prime \prime}$. Slightly brackish temporary pools (10-15×2-4 m, $1 \mathrm{~m}$ maximum depth), irregular in shape, close to the sea.

5. Confluence of Isonzo and Torre rivers, Villesse (Gorizia): $12 \mathrm{~m}$ a.s. $1,13^{\circ} 25^{\prime} 28^{\prime \prime} \mathrm{N}, 45^{\circ} 48^{\prime} 57^{\prime}$ 'E. Small rainpools (4 m diameter, $0.6 \mathrm{~m}$ maximum depth), in the gravels along the banks of the river.

6. Near the factory Grandi Motori, Bagnoli della Rosandra (S. Dorligo della Valle, Trieste): $50 \mathrm{~m}$ a.s.l., $13^{\circ} 50^{\prime} 59^{\prime} \mathrm{N}, 45^{\circ} 35^{\prime} 39^{\prime \prime}$. Temporary pools $(4 \times 2 \mathrm{~m}$, $0.1 \mathrm{~m}$ maximum depth), inside the ruts left by the vehicles.

7. Near the pond of Rupingrande ( $n^{\circ} 10$ of pond cadastre, Monrupino, Trieste): $336 \mathrm{~m}$ a.s.1., $13^{\circ} 48^{\prime} 01^{\prime \prime} \mathrm{N}$, $45^{\circ} 43^{\prime} 43^{\prime}$ "E. Small pools $(3 \times 2 \mathrm{~m}$, less than $0.1 \mathrm{~m}$ maximum depth), excavated in the "red ground" on the karstic plateau, close to a pond; aquatic vegetation absent. 


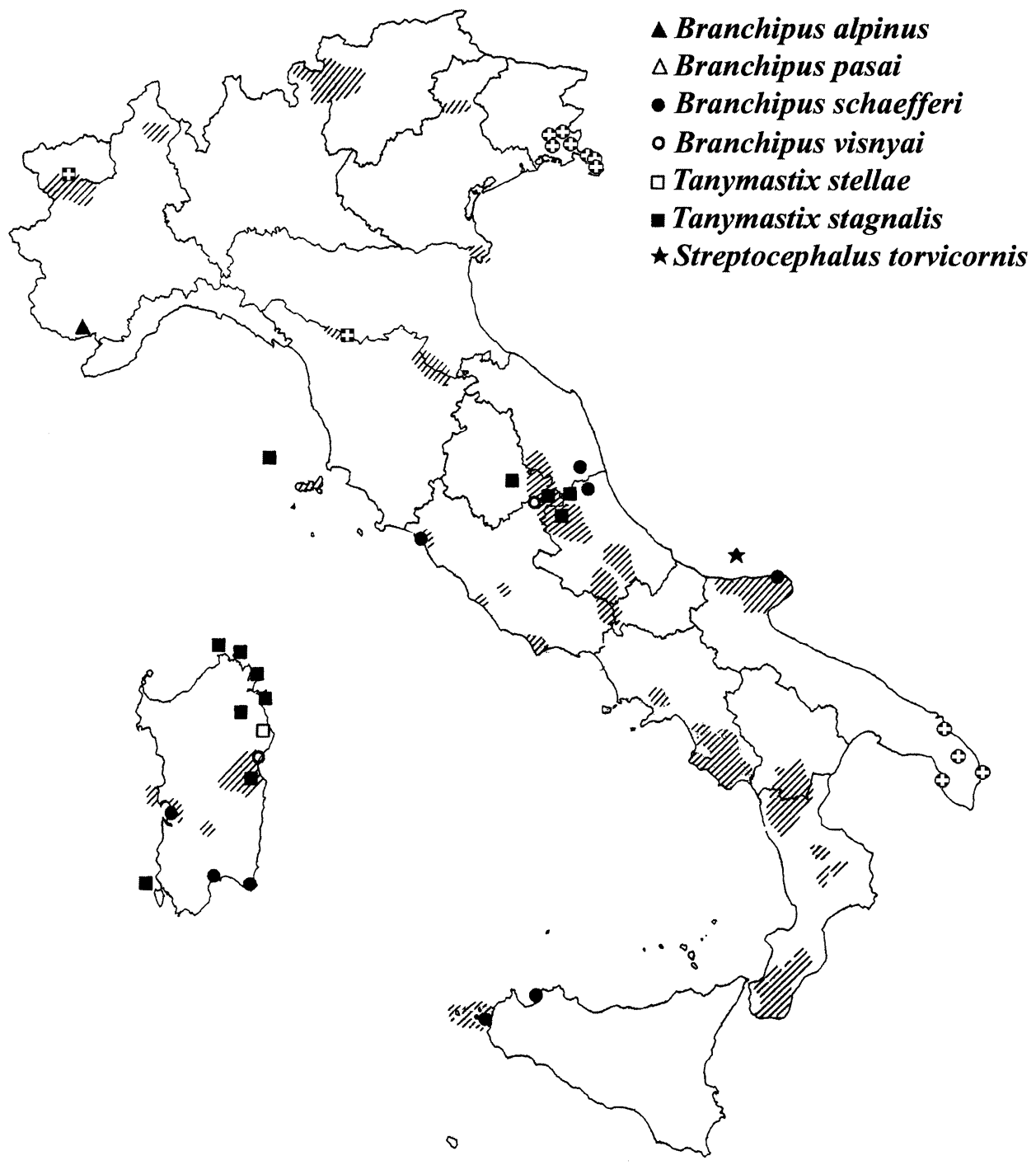

$\Delta$

Fig. 1. Map showing known distribution of Branchipodidae and Streptocephalidae. Recent find spots for Branchipus schaefferi and Tanymastix stagnalis are labelled in white crossed symbols. Shaded fields indicate protected areas.

8. Borgo Grotta Gigante (Sgonico, Trieste): $270 \mathrm{~m}$ a.s.l., $13^{\circ} 45^{\prime} 29^{\prime} \mathrm{N}, 45^{\circ} 42^{\prime} 23^{\prime \prime} \mathrm{E}$. Permanent rockpools (ranging in size from 2 to $5 \mathrm{~m}^{2}, 10-25 \mathrm{~cm}$ depth), formed by dissolution of the limestone.

9. SE of Palmanova walls, Palmanova (Udine): $25 \mathrm{~m}$ a.s.1., $13^{\circ} 18^{\prime} 54^{\prime \prime} \mathrm{N}, 45^{\circ} 54^{\prime} 01^{\prime \prime} \mathrm{E}$. Temporary pools in the fields surrounding the walls of a town, in small depressions (4 $\mathrm{m}$ diameter, $0.2 \mathrm{~m}$ maximum depth); aquatic vegetation absent.

10. Close to the bank of Isonzo River, Fiumicello (Udine): $6 \mathrm{~m}$ a.s.1., $13^{\circ} 26^{\prime} 01^{\prime \prime} \mathrm{N}, 45^{\circ} 47^{\prime} 37^{\prime} \mathrm{E}$. Temporary pools formed by the flooding of the ruts left by the vehicles on a country road; in the gravels along the river banks, irregular in shape $(4-6 \times 1-2$ $\mathrm{m}, 0.2 \mathrm{~m}$ maximum depth); aquatic vegetation absent.

11. Valley of Cedra River (Emilian Appennine): $1676 \mathrm{~m}$ a.s.1. $44^{\circ} 21^{\prime} 50^{\prime} \mathrm{N}, 10^{\circ} 04^{\prime} 49^{\prime \prime}$ E. Pool n'5: elliptical in shape $(10 \times 4 \mathrm{~m}, 30 \mathrm{~cm}$ maximum depth). Submerged and emerging vegetation (Carex sp.).

12. Valley of Cedra River (Emilian Appennine): $1705 \mathrm{~m}$ a.s.1. 4421'56’N, $10^{\circ} 04^{\prime} 25^{\prime \prime}$ E. Pool n'8, circular in shape (20 $\mathrm{m}$ diameter, $50 \mathrm{~cm}$ maximum depth). No vegetation. 


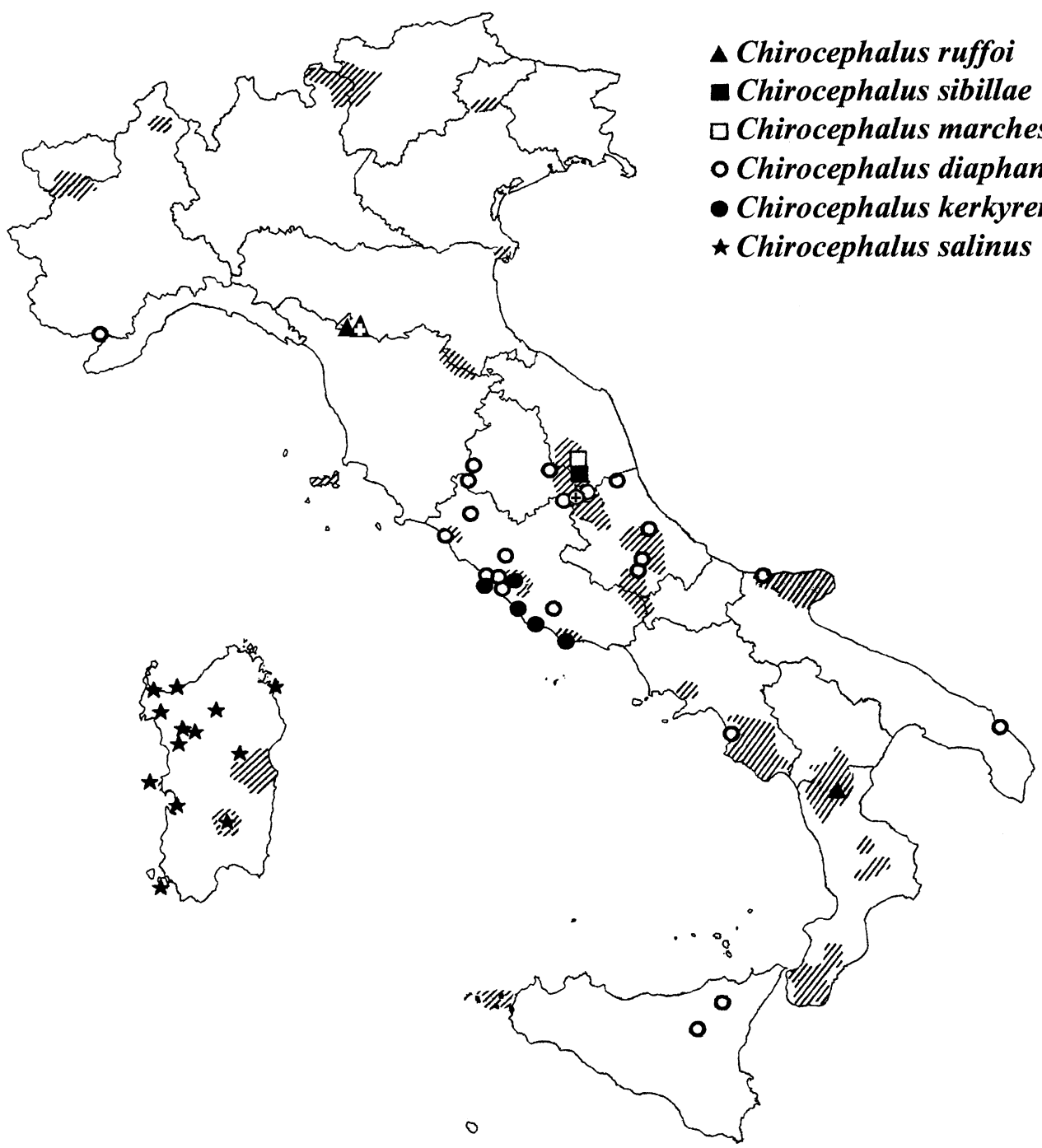

Fig. 2. Map showing known distribution of Chirocephalidae. Recent find-spots for Chirocephalus ruffoi and Chirocephalus diaphanus are labelled in white crossed symbols. Shaded fields indicate protected areas.

13. Gran Paradiso National Park: $2100 \mathrm{~m}$ a.s.l., $45^{\circ} 29^{\prime} 35^{\prime} \mathrm{N}, 7^{\circ} 8^{\prime} 28^{\prime \prime} \mathrm{E}$. Temporary prairie pool elliptical in shape $(4 \times 2 \mathrm{~m}, 25 \mathrm{~cm}$ maximum depth).

14. Porto Badisco (Lecce): 3 m a.s.1., 4004'50”'N, $18^{\circ} 29^{\prime} 07^{\prime \prime}$ E. Temporary pool $(80 \times 40 \mathrm{~m}, 30 \mathrm{~cm}$ maximum depth).

15. Porto Selvaggio (Lecce): $3 \mathrm{~m}$ a.s.1., $40^{\circ} 08^{\prime} 55^{\prime \prime N}$, $17^{\circ} 58^{\prime} 10^{\prime \prime}$. Reduced temporary pool $(3 \times 2 \mathrm{~m}, 30$ $\mathrm{cm}$ maximum depth).

16. Cavallino Castromediano (Lecce): $3 \mathrm{~m}$ a.s.l., $40^{\circ} 19^{\prime} 30^{\prime} \mathrm{N}, 18^{\circ} 11^{\prime} \mathrm{E}$. A rock basin circular in shape $(1 \times 1 \mathrm{~m}, 0.5 \mathrm{~m}$ maximum depth).

17. Montelacquare, Monte Mattia (Castro, Lecce): $70 \mathrm{~m}$ a.s.1., $40^{\circ} 01^{\prime} 00^{\prime \prime} N, 5^{\circ} 58^{\prime} 40^{\prime \prime} E$. Series of very reduced rock-pools (10 cm maximum depth).
18. Monte Nuria (Monti del Cicolano, Fiamignano, Rieti): $1800 \mathrm{~m}$ a.s.1., $42^{\circ} 21^{\prime} 25^{\prime \prime} \mathrm{N}, 13^{\circ} 05^{\prime} 00^{\prime \prime} \mathrm{E}$. Temporary pool elliptical in shape $(80 \times 20 \mathrm{~m}, 0.70$ m maximum depth).

\section{Sardinia}

19. Pauli Is Paious, Nurachi, (Oristano): $1 \mathrm{~m}$ a.s.l, 39॰58'67'N, 9'30'83'E. Hyperaline pond, circular in shape, $(100 \times 75 \mathrm{~m}, 40 \mathrm{~cm}$ maximum depth $)$, without emerging or submerged vegetation.

20. Pesaria (Oristano): $2 \mathrm{~m}$ a.s.1., $39^{\circ} 52^{\prime} 55^{\prime} \mathrm{N}$, $8^{\circ} 34^{\prime} 41^{\prime \prime} \mathrm{E}$, ricefields. 


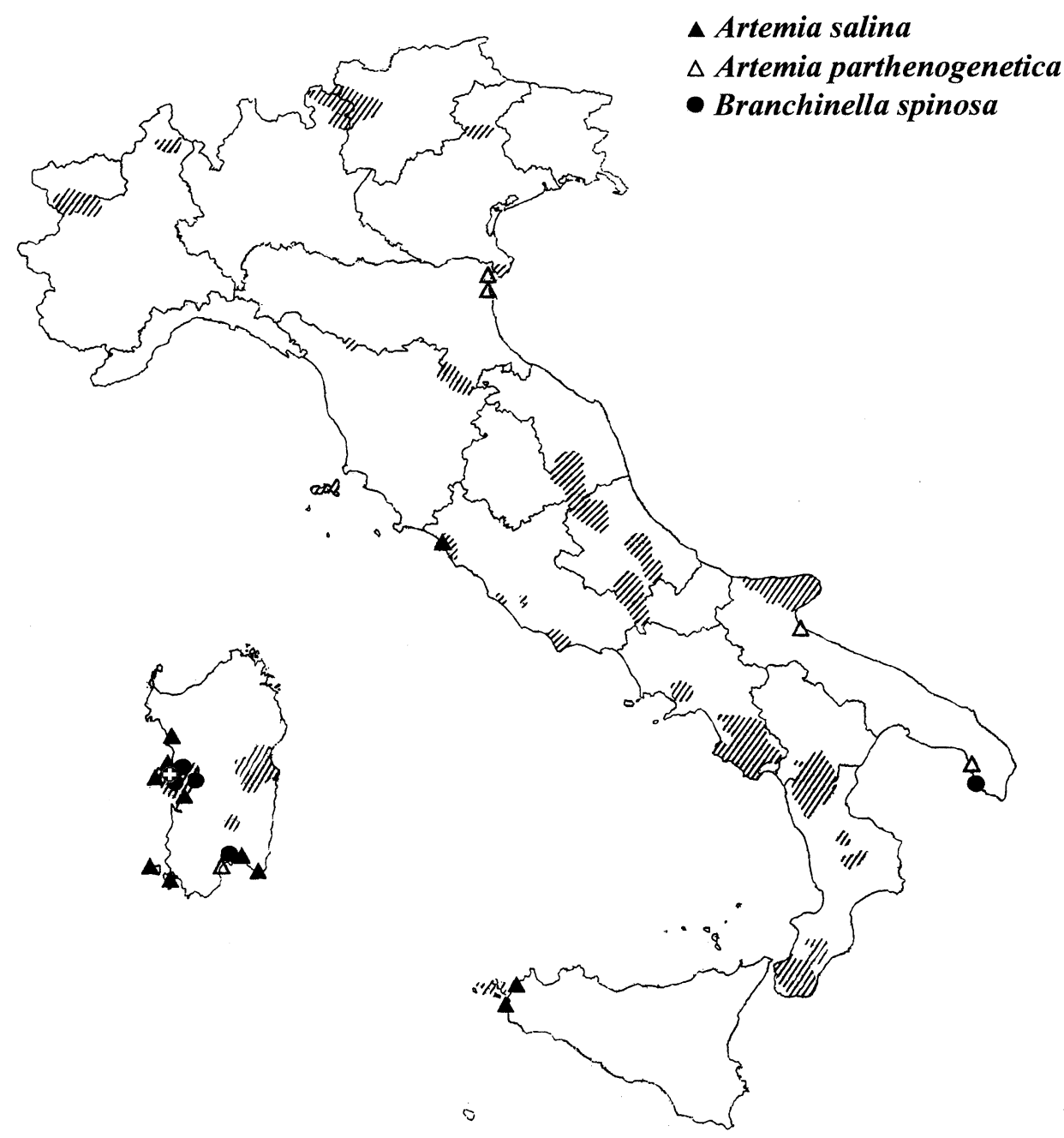

Fig. 3. Map showing known distribution of Artemiidae and Thamnocephalidae. Recent find-spots for Branchinella spinosa are labelled in white crossed symbols. Shaded fields indicate protected areas.

\section{COLLECTED MATERIAL}

\section{Branchipodidae}

Branchipus schaefferi Fischer, 1834

1. 1 え, 04/07/1999, FS leg.

2. 19 spec. (ふふ઼, 웅, juv.), 09/05/1998, FS leg.; 101 spec. (えぶ, 우, juv.), 23/10/1998, FS leg.;16 spec. (ふ̋̂̃, 우, juv.), 16/11/1998, FS leg.

3. 118 spec. (ふふ, 우, juv.), 12/05/1998, FS leg.; 4 spec., 17/11/1998, FS leg.

4. 58 spec. (ふふぇ, 우 juv.), 06/05/1998, FS leg.; 1 우, 23/10/1998, FS leg.

5. $1 \hat{\jmath}, 1$ ㅇ, 14/06/1985, FS leg.; 58 spec. (추, 우우, juv.), 10/06/1990, GC leg.; 10 juv., 06/05/1998, FS leg.

6. 5 spec., 01/05/1994, FS leg.
7. several juv. spec., 08/05/1981, FS leg.; 6 spec., 02/05/1998, NB leg.; 4 spec $(2 \hat{\jmath} \widehat{\jmath}, 2+q)$, $18 / 05 / 1999$, FS leg.

8. $2 \widehat{\jmath} \widehat{\jmath}, 1$ q , 05/06/1998, FS leg.

9. 7 spec., 08/04/1992, SD e FS leg.

10.5 spec., 10/06/1998, NB leg.; 1ð̂, 2 우, 27/05/1999, FS e IZ leg.

14. 10 spec. (3 $\widehat{\jmath}, 7$ 웅), 04/05/1997, DF leg.

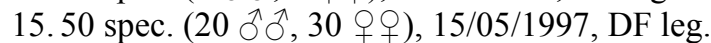

16.30 spec. ( 12 ふ઼่, 18 우우), 20/02/1999, GB leg.

17.10 spec. (4 취, 6 우우), 27/02/1999, DF e RP leg.

20.20 ㅅํ, 30 ovigerous 우우, 20/05/1997, FT leg.

Tanymastix stagnalis (Linnaeus, 1758)

11. 10 ふึうે, 5 우,16/10/1999, GPR LEG.

13.4 ふふふ, 5 우, 30/05/1998, P.Z leg. 


\section{Chirocephalidae}

Chirocephalus ruffoi Cottarelli \& Mura, 1984

$12.15 \hat{\jmath}$ Ðึ, 10 ovigerous 웅,16/10/1999, GPR leg.

Chirocephalus diaphanus Prévost, 1803

18. 20 ふึふ, 35 ovigerous 웅, 27/10/1998, AR leg.

\section{Thamnocephalidae}

Branchinella spinosa Milne-Edwards, 1840.

$19.25 \hat{\jmath}, 30$ q $ᄋ, 10$ subadults, 27/02/2000, GM leg.

\section{GENERAL REMARKS}

With regards to Branchipodidae, the data here presented expand to the north the known range both of Branchipus schaefferi and Tanymastix stagnalis. Of these common species widely distributed in Europe (Brtek \& Thiéry 1995; Eder et al. 1997; Petkowski 1997; Petrov \& Petrov 1997)), the first one was formerly known in our country only for such central and southern regions as Tuscany, Marche, Latium, Apulia, Sardinia and Sicily (Cottarelli \& Mura 1976, 1983, 1995; Mura 1999), whereas no data at all were available for nothern regions. The same is true for the second species, for which information was limited to only three regions of central Italy (Tuscany, Umbria and Latium) (Mura 1999).

The new records confirm the tolerant character of $B$. schaefferi, successfully colonizing temporary water bodies with extremely different characteristics (ricefields, rock-pools, prairie pools and ponds) located at altitudes ranging from sea level to the mountains (Mura 1999).

As to T. stagnalis, its presence in the extreme north of our Peninsula (Alps), as well as in the Central Appennine seems to provide further support to previous literature references on the apparently cold-stenothermal nature of this species (see review in Mura 1999), in contrast to the observations available forAustria, where it may occur at water temperatures of $25-30{ }^{\circ} \mathrm{C}$ (Eder $e t$ al. 1997).

Within the Chirocephalidae, the new finding of Chirocephalus ruffoi, endemic to Italy, contributes further information on the distribution of this species, formerly assumed to be confined to the Pollino National Park (Lucania-Calabria, southern Italy) (Cottarelli \& Mura 1984). The find spot of Val Cedra represents the second one for Central Appennine, the first population of this area having been detected in Monte Rondinaio (ToscoEmiliano Appennine) by Bertolani and coworkers (Rebecchi et al. 1990).

Received: August 2000

Accepted: December 2000
Similarly, the finding of Branchinella spinosa in other Sardinian ponds nearby Oristano (southwestern Sardinia) widens the known range of this species thriving in waters rich in chlorides and sulfates, originally known from a number of coastal ponds (Sale Porcus, Mari Ermi, Sa Mesa Longa, Su Pallosu) of that area, as well as in southern Sardinia (Cottarelli \& Mura 1995; Mura 1999), and recently found also in Peninsular Italy (Mura et al. 1999).

The above recent discoveries illustrate well the many gaps still existing in the coverage of our territory, at least in the case of Branchiopod fauna, and the need for more monitoring and specialists

\section{ACKNOWLEDGMENTS}

The author gratefully acknowledges all of the colleagues contributing specimens to this study.

\section{REFERENCES}

Brtek, J. \& A. Thiéry. 1995. The geographic distribution of the European Branchiopods (Anostraca, Notostraca, Spinicaudata, Laevicaudata). Hydrobiologia, 298: 263-280.

Cottarelli, V. \& G. Mura. 1976. Reperti inediti di Anostraci Italiani. Fragm. Entom., 12: 317-321.

Cottarelli, V. \& G. Mura. 1983. Guide per il riconoscimento delle specie animali delle acque interne italiane. Anostraci, Notostraci, Concostraci. Collana del progetto finalizzato Qualità dell'Ambiente, 18: $71 \mathrm{pp}$.

Cottarelli, V. \& G. Mura. 1984. Chirocephalus ruffoi n. sp.(Crustacea, Euphyllopoda, Anostraca) di acque astatiche d'alta quota dell'Appennino Calabro-Lucano. Boll. Mus. Civ. St. Nat. Verona, 11: 515-523.

Cottarelli, V. \& G. Mura. 1995. Ricerche zoologiche della nave oceanografica "Minerva" (C.N.R.) sulle isole circumsarde. XXV. Ulteriori reperti di anostraci, notostraci e spinicaudati (Crostacei, Branchiopodi) della fauna Italiana. Ann. Mus. Civ. St. Nat."G.Doria", Genova, 90: 599607.

Cottarelli, V., F. Margaritora, G. Mura. 1995. Crustacea, Branchiopoda. Checklist della fauna italiana. Calderini Ed., 26: 1-10.

Eder, E., W. Hödl, R. Gottwald. 1997. Distribution and phenology of large Branchiopods in Austria. Hydrobiologia, 359: 13-22.

Mura, G. 1999. Current status of the Anostraca of Italy. Hydrobiologia, 405: 57-65.

Mura, G., D. Ferreri, G. Belmonte. 1999. Prima segnalazione di Branchinella spinosa Milne-Edwards, 1840 (Crustacea, Branchiopoda, Anostraca) per l'Italia peninsulare. Thalassia Salentina, 23: 59-65.

Petkowski, S. 1997. On the presence of the genus Branchipus Schaeffer, 1766 (Crustacea: Anostraca) in Macedonia. Hydrobiologia, 359: 37-44.

Petrov, B. \& I. Petrov. 1997. The status of Anostraca, Notostraca and Conchostraca (Crustacea, Branchiopoda) inYugoslavia. Hydrobiologia, 359: 29-35.

Rebecchi, L., S. Leonardi \& M.A. Sabatini. 1990. Presenza di Chirocephalus ruffoi Cottarelli \& Mura, 1984 (Crustacea, Anostraca) nell'Appennino Tosco-Emiliano e descrizione del cariotipo. Riv. Idrobiol., 29: 587-595. 